\title{
A Labor Perspective on Globalization
}

THOMAS I. PALLEY

\section{The Debate on Globalization}

Globalization is an enormously controversial subject that is usually presented in terms of technical economic arguments. Aside from being difficult to grasp, conventional economic arguments tend to misrepresent the issue by painting it as a simple pro- versus anti-globalization debate, when the reality is more complex.

For these reasons, the debate on globalization is better viewed through a political lens, in terms of which different political camps emphasize different economic concerns. Considered in such a way there are three major perspectives, as illustrated in Figure I. At the most fundamental level there is a divide between those who see the current structure of globalization as "sound « and those who see it as "problematic."

Figure 1

\section{The Debate on Globalization}

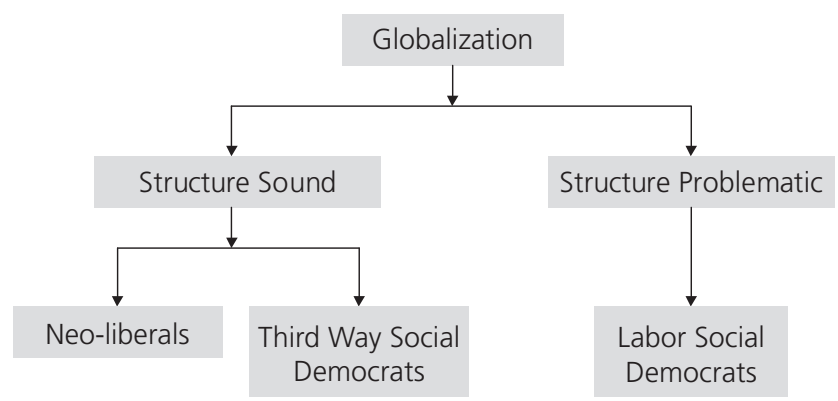

Those viewing globalization as sound can be subdivided into "neoliberals" and "Third Way social democrats. "Neo-liberals believe that globalization is delivering its promised benefits, that in general all bene- 
fit, both within and between countries, and that globalization should continue full steam ahead in its current form. ${ }^{\mathrm{I}}$

Third Way social democrats also believe that globalization is fundamentally sound and delivers positive net benefits to all countries. ${ }^{2}$ However, within countries there are some losers, although total losses are less than total gains. For Third Way social democrats the policy implication is that globalization should continue as is, subject to making compassionate »helping-hand « policy adjustments that target help to those who lose out. ${ }^{3}$

Balanced against these two perspectives is a »labor social democrat « perspective that maintains that the current structure of globalization is fundamentally problematic and therefore needs deeper architectural change. The main features of a labor social democrat perspective are:

I. The current pattern of globalization is hurting many working families and widening social divisions by increasing income inequality.

2. The debate on the size of net gains or losses from globalization misses the point; nor is it an issue of stopping globalization. Instead, the issue is that globalization is being wrongly constructed, and the challenge is to construct a better globalization.

3. Globalization alone does not explain the adverse changes in growth and income distribution, and globalization should not be looked at in isolation. Instead, globalization should be seen as a core element in a new neo-liberal economic paradigm that has been implemented post-I980.

That means that the debate on globalization is ultimately about replacing the larger economic paradigm, which includes the current approach to globalization.

The analytical split among social democrats regarding globalization creates major political difficulties for labor because it internally splits the parties that have traditionally represented labor's interests. This holds for

I. The neo-liberal perspective is exemplified by the us Chamber of Commerce.

2. The Third Way social democrat perspective is exemplified by the Brookings Institute in Washington, DC.

3. An example of »helping-hand " policy is the us proposal for wage insurance, whereby workers who lose their jobs due to trade and suffer wage losses would be compensated by government (Kletzer and Rosen 2005). The argument is that the costs of such programs can be paid for by taxes levied on those who have benefited from globalization. That way everyone can win since the overall gains exceed the losses. 
the Social Democratic Party in Germany, the Labour Party in the United Kingdom, and the Democratic Party in the United States. ${ }^{4}$

As a result, social democrats have been put in a position of structural weakness as regards neo-liberal political parties, and this split confronts labor with a major political conundrum. For labor, the political choices are: (a) have social democrats stick together in fractious union and face the likelihood of steady erosion of historic social democratic aspirations; (b) split and risk full-blown neo-liberal political triumph; or (c) recapture social democratic parties by establishing a new economic consensus.

\section{Economic Trends in the Era of Globalization}

It is difficult to talk meaningfully about the global economy because of its diversity. One important fact (see Tables I and 2) is that average annual global economic growth has been slower post-I973 than in the period 1950-73 (Madison 200I). With regard to income distribution the consensus is that income inequality has been widening within countries (Anand and Segal 2008: 86) and across most countries (Milanovic 2005). ${ }^{5}$

Africa has experienced special political and governance difficulties related to corruption and civil strife, and it has suffered especially sharp deterioration in economic performance despite international economic

4. This split emerged with the political triumphs between 1979 and 1982 of Margaret Thatcher, Ronald Reagan, and Helmut Kohl. That triumph initiated the two-decadelong political dominance of conservative economic ideology, and some social democrats made the decision to embrace part of that ideology. Their argument was that it provided a needed modernization of social democratic thinking, as well as a tactical avenue for regaining political power. The Third Way conversation of Prime Minister Blair, President Clinton, and Chancellor Schröder can be viewed as an attempt to permanently seal this tactical decision by making it the official social democratic creed.

5. China and India have grown very rapidly since 1980. Their large size increases the overall weighted average global growth rate, and also reduces inequality between countries. However, both countries have experienced major increases in inequality within their borders. These two enormous countries complicate the discussion because they grew fast without adopting neo-liberal policies; they did adopt market reforms, however, and also joined the global economy. Their strong performance raises questions concerning whether their growth has been due to adopting market economy principles, their particular combination of state planning plus market forces, or globalization. 
Table 1

Growth of GDP: World and Major Regions, 1950-98 (\%)

\begin{tabular}{|l|c|c|}
\hline & I950-73 & $1973-98$ \\
\hline US & 3.96 & 2.90 \\
Western Europe & $4.8 \mathrm{I}$ & $2 . \mathrm{II}$ \\
Japan & 9.29 & 2.97 \\
Asia ex-Japan & 5.18 & 5.46 \\
Latin America & 5.33 & 3.02 \\
Africa & 4.45 & 2.74 \\
World & $4.9 \mathrm{I}$ & $3.0 \mathrm{I}$ \\
\hline
\end{tabular}

Source: Madison (200I), I26 and I38.

Table 2

Growth of Per Capita GDP: World and Major Regions, 1950-98 (\%)

\begin{tabular}{|l|c|c|}
\hline & $1950-73$ & $1973-98$ \\
\hline US & 2.50 & 2.00 \\
Western Europe & 4.08 & 1.78 \\
Japan & 8.05 & 2.34 \\
Asia ex-Japan & 2.92 & 3.54 \\
Latin America & 2.52 & 0.99 \\
Africa & 2.07 & $0.0 \mathrm{I}$ \\
World & 2.93 & $\mathrm{I} .33$ \\
\hline
\end{tabular}

Source: Madison (200I), I26 and I32.

opening. This shows that openness and global integration do not reduce corruption. Instead, opting for global integration may even worsen corruption by increasing the financial stakes and thereby aggravating the »natural resource curse « that afflicts so many developing countries.

Regional income inequality has increased almost everywhere. Table 3 shows how income shares for the fifth and tenth (top) deciles of the income distribution evolved between 1980 and 2000 in the OECD, Latin America and the Caribbean, East Asia and the Pacific, Africa, and Central and Eastern Europe. In all regions the income share of the fifth decile 
decreased between 1980 and 2000 , while the income share of the tenth decile increased. This pattern resulted in further income inequality measured by the ratio of the incomes of the fifth to tenth deciles. Africa has the highest income inequality, followed by Latin America and the Caribbean. The OECD has the lowest income inequality, but inequality has been increasing.

Table 3

Evolution of Fifth and Tenth (Top) Decile Income Shares, 1980-2000

\begin{tabular}{|c|c|c|c|c|c|}
\hline & $O E C D$ & $L A C$ & $E A P$ & $A F R$ & $E C E$ \\
\hline Deciles-I980 & $7.6 \%$ & $4.9 \%$ & $5.6 \%$ & $4.0 \%$ & $8 . \mathrm{I} \%$ \\
\hline Deciles-2000 & $7.2 \%$ & $4.7 \%$ & $5.4 \%$ & $3.1 \%$ & $6.5 \%$ \\
\hline Ratio 2000/1980 & 0.95 & 0.96 & 0.96 & 0.77 & 0.80 \\
\hline Decile I0 - I980 & $25.7 \%$ & $4 \mathrm{I} .6 \%$ & $4 \mathrm{I} .2 \%$ & $51.6 \%$ & $22.7 \%$ \\
\hline Decile $10-2000$ & $28.3 \%$ & $43.6 \%$ & $4 \mathrm{I} .3 \%$ & $54.4 \%$ & $30.9 \%$ \\
\hline Ratio 2000/1980 & I.IO & I.O5 & I.OO & I.O5 & I. 36 \\
\hline s/Io Ratio - I980 & 0.30 & O.I2 & O.I4 & 0.08 & 0.36 \\
\hline S/Io Ratio - 2000 & 0.25 & O.II & O.I4 & 0.06 & $0.2 \mathrm{I}$ \\
\hline
\end{tabular}

Note: $\mathrm{LAC}=$ Latin America \& Caribbean, EAP = East Asia \& Pacific, AFR = Africa, ECE = East \& Central Europe.

Source: Dikhanov (2005) and author's calculations.

In many regards the us exemplifies the problematic trends of the last three decades. Us median family income evolved relative to an index of productivity over the period I947-2005. Until the late I970s the two series moved together, but since then median family income has become detached from productivity (Figure 2). ${ }^{6}$

Figure 3 shows how average hourly compensation of production and non-supervisory workers evolved relative to productivity between 1959 and 2005 . Such workers represent 80 percent of employment, and total compensation encompasses all benefits, including health insurance. Once again, compensation and productivity tracked closely until the late I970s, but thereafter compensation stagnated while productivity continued to grow.

6. Figures 2, 3, and 4 are from the Economic Policy Institute; Washington, DC. 
Figure 2

Median Family Income and Productivity, 1947-2005

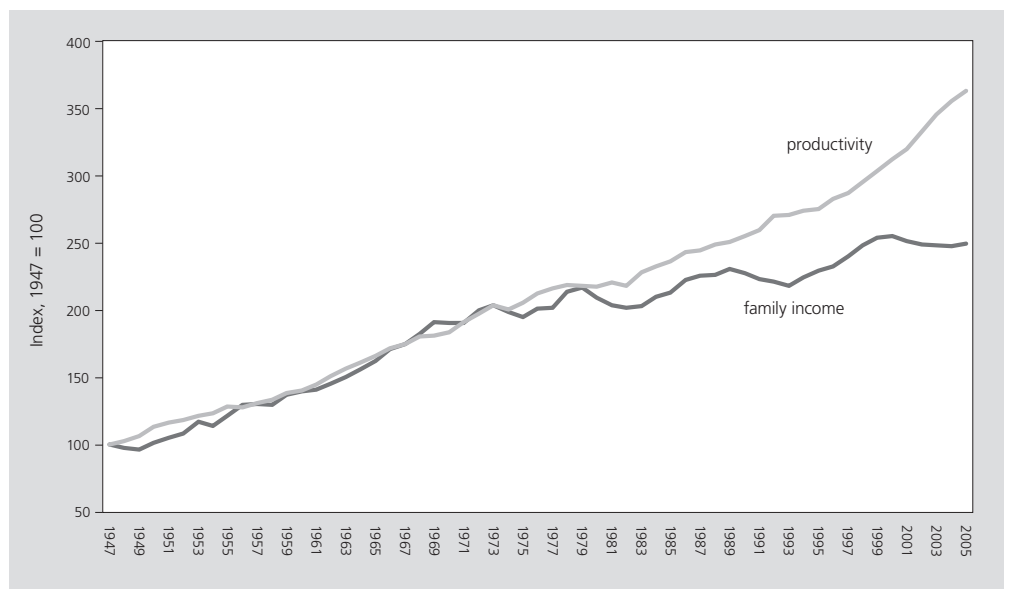

Figure 3

Index of Productivity and Hourly Compensation of Production and Non-supervisory Workers, 1959-2005

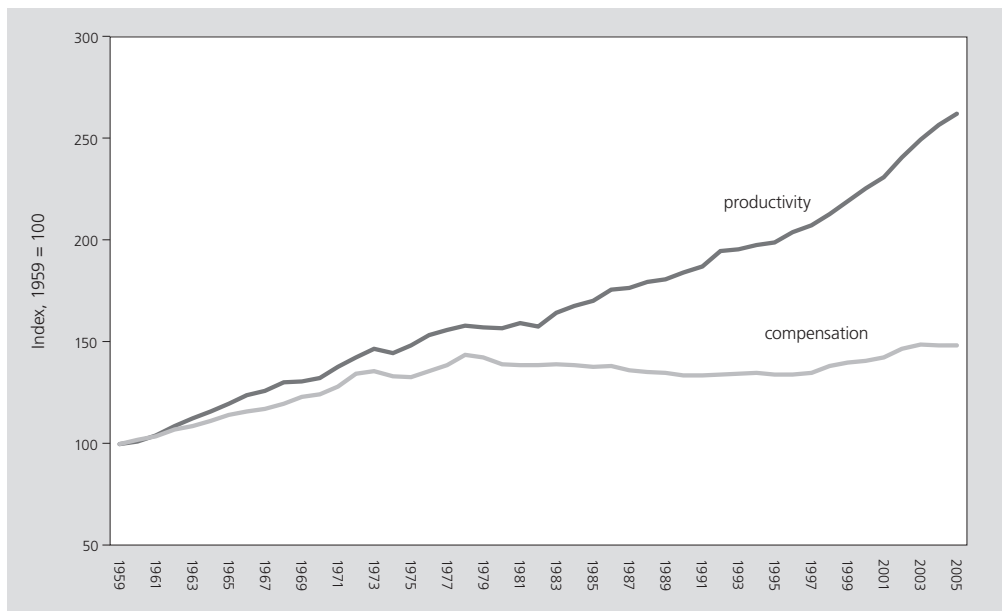


Figure 4

Index of Low Family Income \& High Family Income, 1947-2005

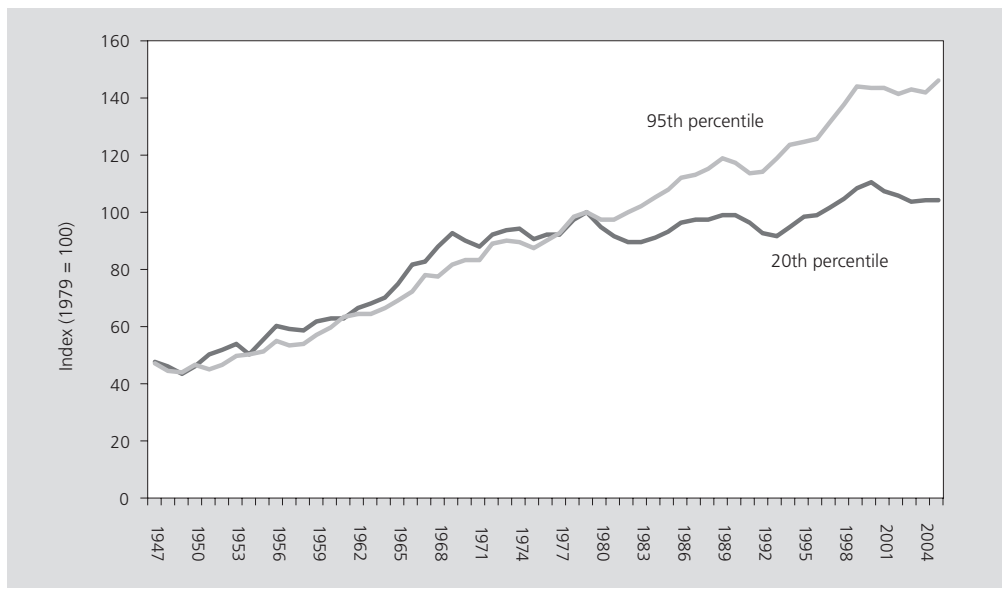

Source: Mishel et al. (2007): The State of Working America 2006/2007, an Economic Policy Institute book. Ithaca, NY: Cornell University Press.

Finally, Figure 4 illustrates the evolution of low family income (2oth percentile) and high family income (95th percentile) for the period 1947-2005. Again, the two tracked together until the late I970s, but since then low family income has stagnated while high family income has grown rapidly. The result of this divergence has been a widening of income inequality.

The core problem afflicting the us economy is the disconnection of worker wages from productivity post-I980. That disconnect explains wage stagnation and rising income inequality, and a similar disconnect probably affects many other industrialized countries. Restoring the link between wages and productivity growth represents labor's central challenge in the era of globalization.

\section{The New Economics of Globalization}

Globalization is widely believed to be a contributory factor in these adverse wage and income inequality developments, and the implementa- 
tion of appropriate policy remedies therefore requires an understanding of the economics of globalization.

Unfortunately, the economics of globalization is not well understood and globalization is frequently conflated with trade. Whereas trade has long been part of the global economy, globalization is a qualitatively new phenomenon involving the creation of globally flexible production networks in which production can be readily shifted between countries. Globalization could not proceed without it, but globalization is far more than trade. Treating globalization as if it was simply trade explains why policy has come up short and failed to address the challenges.

The new global production networks that are the essence of globalization involve three main building blocks:

I. Changed technological and organizational conditions that have created a new world of »barge economics « in which capital and technology are globally mobile.

2. Changed competitive conditions brought about by the adoption of a new global sourcing business model.

3. Neo-liberal trade and financial policies that have removed barriers to international movements of goods and money.

The troubling effects of these systemic changes have been further amplified by the addition of two billion workers to the global labor supply owing to the end of economic isolationism in China, India, and the former Soviet bloc (see below).

\section{Barge Economics: The New Model of Production ${ }^{7}$}

According to classical theory the pattern of trade is explained by the principle of comparative advantage: all can benefit when countries specialize in producing those things in which they have a comparative advantage. A key assumption is that the means of production (capital and technology) are internationally immobile (that is, fixed in each country).

Globalization challenges this assumption, thereby deconstructing classical trade theory's foundation. Jack Welch, former CEO of General Electric, captured the new reality when he talked of ideally having »every plant you own on a barge." Welch envisioned factories floating between countries to take advantage of the lowest costs, be they due to undervalued exchange rates, low taxes, subsidies, or low wages.

7. This section draws on Palley 2008a, $2008 \mathrm{~d}$. 
Globalization has made Welch's barge a reality, creating a new world of »barge economics. «In this new world, capital mobility determines the pattern of trade rather than comparative advantage, with factories moving to wherever costs are lowest. As a result, so-called "free trade« increasingly trades jobs, which move with the barge.

Additionally, barge economics promotes downward equalization of wages and standards by fundamentally changing the balance of bargaining power between workers and corporations, and by changing the margins of competition between countries. Think of two swimming pools with different levels of water: barge economics joins the pools together, causing the water to equalize at the lower level.

\section{Global Sourcing: The New Model for Buying ${ }^{8}$}

Global sourcing is a second critical element of globalization. Barge economics represents a new model of global production (the supply side). Global sourcing represents a new model of buying (the demand side). Together they leverage each other and fundamentally change the nature of global competition.

Global sourcing has evolved gradually over the past sixty years, beginning with the growth of multinational corporations in the r950s and I960s. The role of multinationals has received much attention, but less noticed and equally important is the "retail revolution " based on socalled »big box « discount stores, exemplified by Wal-Mart. These stores have been a key driver of globalization.

Wal-Mart was established in 1962, and it immediately created a "national buying " model in terms of which it bought goods from manufacturers all around the us, thereby placing manufacturers in a nationally competitive market. In the I980s big box discounters like Wal-Mart shifted to a global buying model, changing the scale of the phenomenon. This global buying model has big box discount retailers scour the world for the lowest price (the so-called »China Price«), which puts countries in competition. This creates North-North competition, North-South competition, and South-South competition, and puts each country's entire manufacturing sector in international competition. As a result, the global buying model erodes manufacturing jobs and wages, and its commercial success forces all retailers to adopt it or face elimination.

8. This section draws on Palley $2008 \mathrm{c}$. 
Offshore outsourcing represents an application of the retailers' global sourcing model to manufacturing. It is exemplified by recent developments in the US auto-parts industry that have affected companies such as Delphi and Visteon. These companies were originally subsidiaries of General Motors and Ford. In the r99os they were spun off and placed in national competition with other us parts makers, but still retained some preferential supply-standing with their former corporate parents. That standing has now been abandoned and Delphi and Visteon have been placed in international competition, with General Motors and Ford asking their former in-house parts suppliers to meet the "China Price« or lose the business.

The same process is occurring in aerospace, with Boeing's new 787 Dreamliner being sourced on a global basis. Peering into the future, trade in services looks like being the next area of application of the global sourcing model, and the Internet means even retail can potentially be out-sourced.

\section{The Role of International Economic Policy}

The third critical element in the creation of the new global economic system is trade and international financial policy. Trade policy has worked to remove barriers to cross-country movement of goods, while financial policy has worked to remove barriers to cross-country movement of finance. Trade policy has also worked to secure property rights and investors' rights.

These policy developments have been essential for globalization, and they have leveraged and multiplied the effects of barge economics and global sourcing. Absent these policy changes, global production networks would be far less viable owing to the costs of moving goods, lack of investor confidence, and inability to finance these arrangements.

\section{Two Billion Additional Workers}

By itself the abovementioned economic cocktail would have produced downward pressure on wages and income distribution. However, these structural changes have been accompanied by the addition of two billion additional workers resulting from the end of economic isolationism in India, China, and the former Soviet bloc, which makes their effect even greater. Moreover, this labor supply impact can be expected to 
continue for years as the process of absorbing so many workers will take decades. China has played an especially significant role as it alone has approximately 750 million active workers and is a preferred location for MNC production. That has resulted in a flood of capital and technology into China, which has made it the global low price supplier for big box retailers and increasingly for manufacturing outsourcing. This impact is exacerbated by China's specific economic policies that encourage exportled growth and inflows of foreign investment through an undervalued exchange rate, wage suppression, and unfair trading practices such as subsidies, domestic content requirements, and production offsets.

Finally, China's impact afflicts both North and South. With regard to the North, China competes with large segments of Northern manufacturing, causing job losses and reduced investment. With regard to the South, China attracts foreign investment that might otherwise have gone to other developing countries, while its policies of export-led growth lower the price of low-end manufactured goods that are also produced by other developing countries. China's huge labor surplus pulls down wages in the North, while preventing them from rising in the South.

\section{Globalization as Part of Neo-liberalism}

Globalization is often talked of as if it were a natural phenomenon. Such talk distorts understanding and diminishes the political space for alternatives. Not only is globalization significantly a policy creation, but it should also be understood as an integral part of a larger neo-liberal policy agenda. Thus, globalization fits into a larger economic policy program developed by corporate elites and aimed at benefiting business. That makes globalization as much a product of corporate planning as of the invisible hand.

The neo-liberal policy program can be described as »boxing in « workers, as illustrated in Figure $5 .{ }^{9}$ Workers are put inside the box and are then pressured on all four sides. The left side of the box has globalization pressuring workers through international competition. The right side has workers pressured by the push for small government, which aims to shrink the size of the public sector, lower public sector wages, and reduce

9. The notion of the neo-liberal box is attributable to Ron Blackwell of the AFL-CIO (American Federation of Labor and Congress of Industrial Organizations). 
Figure 5

The »Neo-liberal« Policy Box

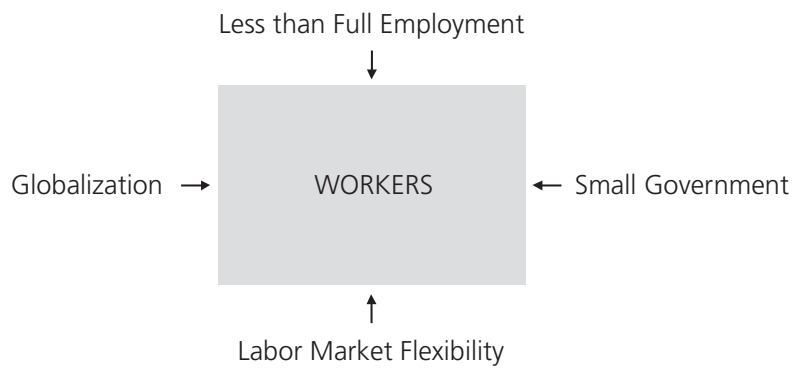

public sector provision of services. The upper edge has workers pressured by a retreat from the commitment to full employment, which is replaced by a focus on low inflation that is justified ideologically on the grounds of a »natural rate of unemployment. « Finally, the lower edge of the box pushes for labor market flexibility that principally aims to weaken unions and labor market protection, thereby increasing the threat effect of unemployment and weakening workers' bargaining power.

Workers cannot outrun the consequences of this box, and both private and public sector workers are boxed in. All workers feel the pressure of labor market flexibility and the retreat from full employment, while private sector workers are pressured in particular by globalization and public sector workers by the push for small government. Southern workers are also pressured because the neo-liberal agenda has been applied in developing countries, too, and globalization (that is, barge economics and global sourcing) also puts Southern workers in competition with each other, as described earlier.

Governments are also boxed in. Mobility of investment and production creates fears of employment losses, while mobility of finance creates vulnerability to financial disruption. These conditions deter progressive policies (such as fair taxation and unionization) by raising their "political cost.« Moreover, it also creates »lock-in « whereby the longer a policy is in place the harder it is to reverse. 


\section{Some Comments on Germany: The Problem of Export-led Growth}

The neo-liberal box provides a generic description of the neo-liberal paradigm, but there are also country-specific differences. Among industrial countries Germany represents a special situation, though it may be shared to some degree by Japan. In particular, Germany has remained a manufacturing powerhouse and is also a heavily export-oriented economy, which might lead one to believe that it benefits from neo-liberal globalization. However, closer inspection shows that globalization is problematic for Germany, too.

First, like other countries, Germany has been subject to wage competition from less developed economies, especially those in Central Europe. Thus, even Germany's famed auto and engineering sectors have felt the threat effects of manufacturing relocation to Poland, Hungary, the Czech Republic, and Slovakia.

Second, Germany's export-led paradigm poses problems for the global economy that ricochet back to Germany. This is because one country's exports are another's imports, which means that not all countries can rely on export-led growth. If all try to run trade surpluses the result must be a global shortage of buyers that produces global unemployment and deflation. Moreover, even if a few try it, those few inflict a negative externality on other countries by poaching their demand. ${ }^{\text {Io }}$ Thus, Germany, which relies on the global economy to provide demand, may have weakened growth in other countries and contributed to the global financial imbalances that are behind the current financial crisis.

With global growth now weakening, Germany is feeling two significant negative effects. First, its reliance on exports and neglect of German domestic demand mean that it is vulnerable to the global economic slowdown. Second, Germany's trade surplus has made it vulnerable to financial contagion. This is because its trade surpluses were invested in Us financial assets, thereby providing a corridor of contagion into the German financial system.

IO. This fundamental problem was identified long ago by the economist Joan Robinson (I966) who characterized it as »beggar-thy-neighbor « economics, whereby countries rely on other countries for growth. Export-led growth also poses a problem for developing economies as they crowd each other out in trying to gain market share in industrialized economies (Palley 2003). 
Ironically, Germany's trade surplus required giving up consumption, yet Germany now finds itself afflicted by financial instability and the financial assets it received for its exports are considerably reduced in value. That suggests a better outcome for Germany would have been to export less and consume more - but that requires dismantling the neo-liberal policy box so that German workers can bargain the higher wages needed to support higher consumption.

\section{How Should Labor Respond?}

The neo-liberal box is built upon economic policy, which means that changing economic policy is critical. Social policy, in the form of helpinghand policies for displaced workers, is always welcome but it cannot substitute for changing economic policy.

\section{Repacking the Box}

For labor the goal must be to replace the neo-liberal policy agenda with a social democratic agenda that repacks the box, taking workers out of the box and putting corporations and financial markets in. Such an alternative box is illustrated in Figure 6. It involves globalization with standards and restrictions on adverse forms of competition; full employment policy; restoring workers' bargaining power; and reviving a social democratic vision of government that provides generously for education, social and health insurance, public goods, and public infrastructure.

Figure 6

Repacking the Box

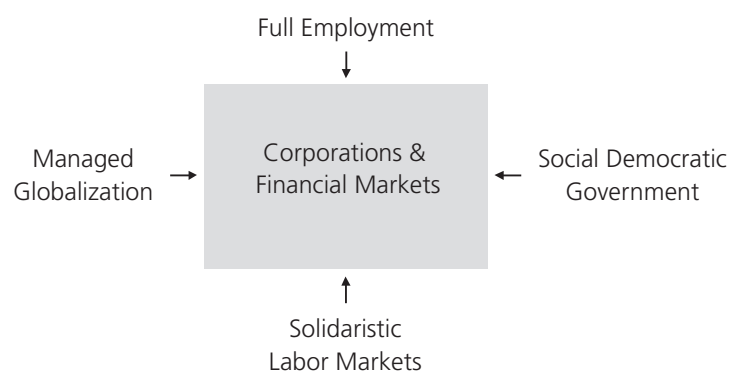


The neo-liberal policy box represents the face of neo-liberalism, and it is tempting to immediately jump to standard policy recommendations. However, that would be a mistake. Instead, it is necessary to understand more deeply what holds the box together, and then to address those aspects.

Figure 7

Lifting the Lid and Unpacking the Box

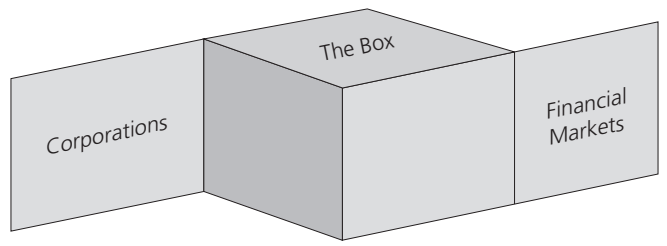

Figure 7 shows how the neo-liberal box rests on the power of corporations and financial markets, which combine in a new phenomenon that has been labeled »financialization « (Epstein 200I; Palley 2008b). Absent these side-supports the box would fold.

Figure 8

\section{Dynamics of Financialization}

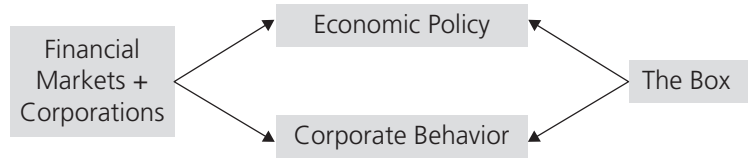

Figure 8 illustrates how financialization operates. Financial market interests have seized control of corporations, and the combination of the two drives neo-liberal policy in the political arena and short-term financially-oriented behavior in the corporate arena.

Such behaviors undermine long-run growth, put persistent downward pressure on wages, and worsen income distribution. The full nature of their deleterious effects was masked for many years by asset price inflation and rising debt that maintained demand, but they are being starkly revealed by the current financial crisis. 
Analytically, the important implication is that it is not enough to repack the box by changing the "policy mix. «There is also need for a deeper policy agenda addressing financial markets and corporations. In a sense, financialization is the economic foundation of neo-liberalism, which means that reversing the neo-liberal paradigm requires a policy agenda addressing financial markets and corporations. That agenda must aim to re-align the behaviors of both financial markets and corporations so that they incorporate a greater public interest.

\section{Changing the Climate of Economic Opinion}

Politics is critical to overthrowing neo-liberal policy and repacking the box. This is because political power is needed to change the direction of policy. However, as with the debate on globalization, labor is again poorly positioned because social democrats are also split on the issue of neoliberalism. This split is illustrated in Figure 9. Third Way social democrats think that the neo-liberal policy paradigm is basically sound, but is in need of some compassionate »helping-hand " policies to assist the »invisible hand." Conversely, labor social democrats think that the neo-liberal paradigm is fundamentally misguided and the box needs repacking.

Figure 9

\section{The Political Dilemma of Neo-liberalism}

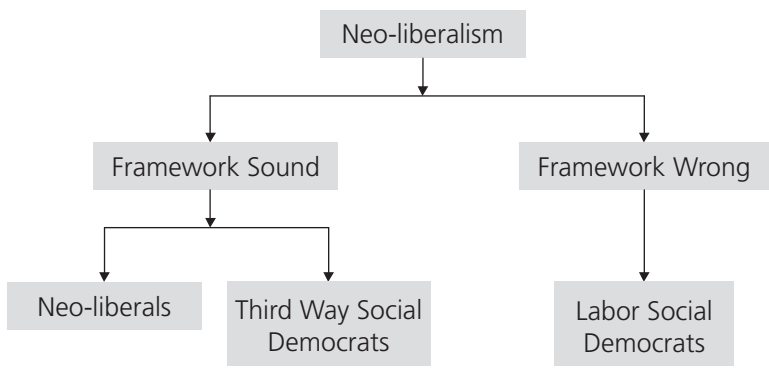

This split means that electing social democratic governments in the current environment is at best a holding strategy. More likely, neo-liberalism will continue to entrench itself inch by inch, even when social democrats are in government.

That points to the fact that standard electoral politics are insufficient. Rather, there is a need to fundamentally change the national economic 
policy debate. Such change requires transforming the ideas that frame economic thinking - what Friedman called the "climate of opinion."

To use a sports metaphor, for the past thirty years neo-liberals and market fundamentalists have controlled the political playing field by conducting the national economic conversation. That control has given neoliberals an enormous advantage, placing labor persistently on the policy defensive. It compares with the thirty years from 1945 to 1975 when the ideas of Keynes and Franklin Roosevelt's New Deal dominated thinking. During that earlier period social democrats defined the policy playing field and neo-liberals were on the defensive.

Labor's challenge is to reconfigure the political and policy playing field by recapturing the national economic conversation. That is a deeper and broader task than conventional economic policy analysis. It involves constructing a compelling economic vision supported by economic logic that justifies the policies labor advocates.

The political experience of the past two decades shows that technically good policy alone is unconvincing. Policy also needs to be connected to a logically compelling economic vision that has widespread public understanding and support. Labor has to promote and communicate that vision. History shows that if labor persuades people about how the economy works, political support will quickly be forthcoming for its policies.

The current moment of crisis and accumulated discontents opens a window for political change. However, change will be deep and longlasting only if labor regains control of the climate of opinion. Absent change in deep economic understanding, political victory is likely to prove fragile and temporary, and easily swept away by everyday political misfortunes or sudden bad economic news. Bringing about such a change calls for a new intensive engagement with economics and economic policy by labor. That engagement has been missing for the past thirty years.

\section{Conclusion}

Labor is not opposed to globalization. It is opposed to the current pattern of globalization that too often harms working families and has contributed to the disconnection of wages from productivity growth.

This pattern of globalization is part of a larger neo-liberal economic policy paradigm that boxes workers in, undermining their bargaining power and putting persistent downward pressure on wages and working 
conditions. That means that the debate over globalization is ultimately part of a larger debate on neo-liberalism. The neo-liberal paradigm not only persistently pressures workers, but also tells a story that legitimizes this pressure by claiming that the economy can work only if wages are suppressed. From a neo-liberal perspective the price of employment is wage suppression. Moreover, managers are also pressured by the system so that even those firms that might want to choose a different path cannot do so because of global competitive threats. This illustrates the systemic nature of the problem. It is not a matter of fine-tuning existing policy, but rather of replacing neo-liberalism with a new economic paradigm.

\section{References}

Anand, S. and P. Segal (2008): »What Do We Know about Global Income Inequality? « in: Journal of Economic Literature, 46:1: 57-94.

Dikhanov, Y. (2005): Trends in Global Income Distribution 1970-2000, and Scenarios for 20I5, Occasional Paper, Human Development Report Office, UNDP.

Epstein, G. (200I): »Financialization, Rentier Interests, and Central Bank Policy,» manuscript, Dept. of Economics, University of Massachusetts, Amherst, MA.

Kletzer, L.G. and H. Rosen (2005): »Easing the Adjustment Burden on Workers, « in: C.F. Bergsten (ed.): The United States and the World Economy: Foreign Economic Policy for the Next Decade. Washington DC: Institute for International Economics. Madison, A. (200I): The World Economy: A Millennial Perspective, Paris: OECD.

Milanovic, B. (2005): Worlds Apart: Measuring International and Global Inequality. Princeton and Oxford: Princeton University Press.

Palley, T. I. (2003): »Export-led Growth: Evidence of Developing Country Crowdingout, « in: Arestis, Badley, and McCombie (eds.): Economic Integration, Regionalism, and Globalization. Cheltenham: Edward Elgar.

_- (2008a): »Barge Economics: The New Economics of Globalization, « Testimony presented to the Subcommittee on Investigation and Oversight, House Committee on Science and Technology, U.s. Congress, Washington DC (June 24, 2008).

- (2008b): »Financialization: What It Is and Why It Matters, « Working Paper 04/2008, IMK Macroeconomic Policy Institute; Düsseldorf, Germany.

- (2008c): "The Economics of Outsourcing: How Should Policy Respond?, « in: Review of Social Economics, 66:3: 279-95.

- (2008d): "Institutionalism and New Trade Theory: Rethinking Comparative Advantage and Trade Policy, in: Journal of Economic Issues, XLII (March): 195-208.

Robinson, J. (1966): The New Mercantilism. An Inaugural Lecture. Cambridge: Cambridge University Press. 